\title{
EFFECTS OF EMPAGLIFLOZIN AND L-ORNITHINE L-ASPARTATE ON BEHAVIOR, COGNITIVE FUNCTIONS, AND PHYSICAL PERFORMANCE IN MICE WITH EXPERIMENTALLY INDUCED STEATOHEPATITIS
}

Prikhodko VA ${ }^{1 凶}$, Sysoev Yul ${ }^{1,2}$, Poveryaeva MA¹, Bunyat AV ${ }^{1}$, Karev VE ${ }^{3}$, Ivkin DYu ${ }^{1}$, Sukhanov DS ${ }^{1}$, Shustov EB ${ }^{1}$, Okovityi SV ${ }^{1}$

${ }^{1}$ Saint Petersburg State Chemical and Pharmaceutical University, Saint Petersburg, Russia

2 Institute of Translational Biomedicine, Saint Petersburg State University, Saint Petersburg, Russia

${ }^{3}$ Pediatric Research and Clinical Center for Infectious Diseases of FMBA, Saint Petersburg, Russia

Non-alcoholic fatty liver disease (NAFLD) is a chronic condition characterized by disturbed carbohydrate and lipid metabolism and often complicated by psychoneurological symptoms, including anxiety, depression, memory deficit, and asthenia. Most studies of pharmacotherapy candidates for NAFLD focus on the ability of the tested drugs to restore the biochemical functions and morphology of the liver while their potential effects on the co-existing conditions remain overlooked. The aim of this paper was to investigate the effects of empagliflozin and L-ornithine L-aspartate (OA) on behavior, memory, and physical performance in C57BL/6 mice with experimentally induced NAFLD (6 months of a Western diet + weekly carbon tetrachloride injections). The disease affected animal behavior (locomotion speed decreased by $38 \%$ and $35 \%, p<0.01$; rearing increased by $432 \%$ and $279 \%, p<0.05$ etc.), induced long-term memory deficit (latency to find the target box increased by $108 \%$ in the Barnes maze, the number of errors increased by $439 \%, p<0.05$ ), and compromised physical performance (swimming time in the forced swim test dropped by $50 \%, p<0.05$ etc.). When administered during the high-calorie diet period, both drugs reduced anxiety (empagliflozin: the number of grooming bouts rose by $160 \%, p<0.05$ and $2173 \%, p<0.01$; time spent in the light compartment in the light/dark box test increased by $275 \%$, $p<0.05$, etc.; OA: time spent in the open arms of the maze increased by $267 \%, p<0.05)$, and promoted memory retention in mice with NAFLD. OA improved physical performance (swimming time in the forced swimming test improved by $106 \%, p<0.05$, etc.). Thus, empagliflozin and OA can have a beneficial effect on cognitive functions, as well as behavior, and ameliorate asthenia in NAFLD.

Keywords: non-alcoholic fatty liver disease, steatohepatitis, cognitive disorders, physical performance, empagliflozin, L-ornithine L-aspartate

Funding: this work was part of the Saint-Petersburg State University project № 51134206.

Author contribution: Prikhodko VA analyzed the literature; conducted the experiments; participated in statistical analysis and interpretation of the obtained data; wrote the manuscript and prepared the figures. Sysoev Yul planned the study; analyzed the literature; conducted the experiments; participated in statistical analysis and data interpretation; wrote the manuscript and prepared the figures. Poveryaeva MA conducted the experiments; Bunyat AV planned the study; conducted the experiments; Karev VE analyzed and interpreted the obtained data; wrote the manuscript and prepared the figures; Ivkin DYu planned the study; analyzed the literature; Sukhanov DS planned the study; analyzed and interpreted the obtained data; wrote the manuscript; Shustov EB, Okovityi SV planned the study; analyzed the literature; analyzed and interpreted the obtained data; wrote the manuscript.

Compliance with ethical standards: the experiments were conducted in compliance with the Basel Declaration, the Order № 199 on the Principles of Good Laboratory Practice of the Ministry of Healthcare of the Russian Federation dated April 01, 2016, and the recommendations of the Bioethics Committee of Saint Petersburg State Chemical and Pharmaceutical University. The animals were housed in a vivarium under standard controlled laboratory conditions.

$\triangle$ Correspondence should be addressed: Veronika A. Prikhodko

Krasnoputilovskaya, 76, k. 2, lit. A, Saint Petersburg, 196247; veronika.prihodko@pharminnotech.com

Received: 22.05.2020 Accepted: 08.06.2020 Published online: 20.06.2020

DOI: $10.24075 /$ brsmu.2020.034

\section{ВЛИЯНИЕ ЭМПАГЛИФЛОЗИНА И L-ОРНИТИНА L-АСПАРТАТА НА ПОВЕДЕНЧЕСКО-КОГНИТИВНЫЕ ФУНКЦИИ И ФИЗИЧЕСКУЮ РАБОТОСПОСОБНОСТЬ ПРИ ЭКСПЕРИМЕНТАЛЬНОМ СТЕАТОГЕПАТИТЕ}

В. А. Приходько ${ }^{1 凶}$, Ю. И. Сысоевв ${ }^{1,2}$ М. А. Поверяева ${ }^{1}$, А. В. Бунят ${ }^{1}$, В. Е. Карев ${ }^{3}$, Д. Ю. Ивкин ${ }^{1}$, Д. С. Суханов ${ }^{1}$, Е. Б. Шустов ${ }^{1}$,

С. В. Оковитый

' Санкт-Петербургский государственный химико-фармацевтический университет, Санкт-Петербург, Россия

${ }^{2}$ Институт трансляционной биомедицины, Санкт-Петербургский государственный университет, Санкт-Петербург, Россия

${ }^{3}$ Детский научно-клинический центр инфекционных болезней ФМБА России, Санкт-Петербург, Россия

Неалкогольная жировая болезнь печени (НАЖБП) - хроническое заболевание, характеризующееся не только изменениями углеводного и липидного обменов, но и рядом психоневрологических нарушений, включая тревожно-депрессивные расстройства, ухудшение памяти и астенический синдром. Большинство фармакологических исследований направлено на оценку способности препаратов восстанавливать биохимические функции и гистоморфологическую картину печени при НАЖБП; их влияние на течение сопутствующих нарушений изучают редко. Целью работы было оценить влияние эмпаглифрлозина и L-орнитина L-аспартата (OA) на поведение, память и физическую работоспособность мышей линии C57BL/6 при моделировании НАЖБП (6-месячная «западная диета" с еженедельным введением тетрахлорметана). Данная модель вызывает у животных изменение поведения (снижение скорости передвижения на 38 и 35\%, p < 0,01; увеличение частоты стоек на 432 и 279\%, $p<0$, 05 и др.), ухудшение долговременной памяти (время поиска в «Лабиринте Барнс" возрастало на 108\%, число ошибок - на 439\%, p< 0,05), а также снижение физической работоспособности (время вынужденного плавания сократилось на 50\%, $p<0,05$ и др.). Оба препарата при введении во время диеты снижали тревожность (эмпаглифрлозин: число грумингов возросло на 160\%, $p<0,05$ и на 2173\%, $p<0,01$; время в белой зоне черно-белой камеры — на $275 \%, p<0,05$ и др.; ОА: время в открытых рукавах лабиринта увеличилось на $267 \%, p<0,05)$ и способствовали сохранению памяти у мышей с НАЖБП. Особенностью ОА было повышение физической работоспособности животных (время вынужденного плавания увеличилось на 106\%, p < 0,05 и др.). Таким образом, эмпаглифлозин и ОА могут положительно влиять на поведенческие и когнитивные функции, а также снижать выраженность астенического синдрома при НАЖБП.

Ключевые слова: неалкогольная жировая болезнь печени, стеатогепатит, когнитивные нарушения, физическая работоспособность, эмпаглифлозин, L-орнитина L-аспартат

Финансирование: работа проведена в рамках проекта Санкт-Петербургского государственного университета №: 51134206.

Вклад авторов: В. А. Приходько - анализ литературы, проведение экспериментов; анализ, статистическая обработка и интерпретация данных; подготовка рукописи и иллюстраций. Ю. И. Сысоев - планирование исследования, анализ литературы, проведение экспериментов; анализ, статистическая обработка и интерпретация данных; подготовка рукописи и иллюстраций. М. А. Поверяева - проведение экспериментов; А. В. Бунят планирование исследования, проведение экспериментов; В. Е. Карев - анализ и интерпретация данных, подготовка рукописи и иллюстраций; Д. Ю. Ивкин - планирование исследования, анализ литературы; Д. С. Суханов - планирование исследования, анализ и интерпретация данных, подготовка рукописи; Е. Б. Шустов и С. В. Оковитый — планирование исследования; анализ литературы; анализ и интерпретация данных; подготовка рукописи.

Соблюдение этических стандартов: все эксперименты проводили в соответствии с принципами Базельской декларации, Приказом Минздрава РФ от 01.04.2016 № 199н «Об утверждении правил надлежащей лабораторной практики» и рекомендациям биоэтической комиссии ФГБОУ ВО СПХФУ Минздрава России. Животных содержали в стандартных условиях вивария с соблюдением нормативных требований к питанию и освещению.

$\bigotimes$ Для корреспонденции: Вероника Александровна Приходько ул. Краснопутиловская, д. 76, к. 2, лит. А, г. Санкт-Петербург, 196247; veronika.prihodko@pharminnotech.com Статья получена: 22.05.2020 Статья принята к печати: 08.06.2020 Опубликована онлайн: 20.06.2020 DOI: $10.24075 /$ vrgmu.2020.034 
Non-alcoholic fatty liver disease (NAFLD) is a chronic condition caused by the pathologic deposition of fat in liver cells which does not result from alcohol intake or exposure to toxic substances. NAFLD is closely associated with carbohydrate and lipid metabolism disorders, obesity, and insulin resistance. It is estimated that up to $25 \%$ of the world's population today suffers from NAFLD, suggesting that it is the leading cause of chronic liver disease [1, 2].

Besides metabolic alterations, NAFLD is associated with a number of non-specific symptoms, including depression, anxiety, asthenia, and cognitive impairment [3-5]. A study revealed that $53 \%$ of patients with NAFLD had signs of subclinical depression whereas 14\% were clinically depressed [6]. Mood swings and irritability observed in such patients often co-exist with weakness and chronic fatigue [3]. Some authors hold the opinion that almost all NAFLD patients experience cognitive complications; mild cognitive symptoms are observed in half of such patients, whereas the other half have moderate or severe symptoms [4].

The aims of treatment for NAFLD are to eliminate its causes, mitigate the symptoms and prevent the progression of the disease $[2,7]$. Apart from diet and physical exercise, some patients with NAFLD should be advised to take hypolipidemic, hypoglycemic and hepatoprotective agents [2, 7]. The efficacy of these drugs against metabolic disorders has been studied extensively; however, few publications discuss their use in the therapy of NAFLD-associated psychoneurological deficits $[8,9]$. This paper investigates the effects of empagliflozin and L-ornithine L-aspartate on behavior, cognitive functions, and physical performance in C57BL/6 mice with experimentally induced NAFLD.

\section{METHODS}

The study was carried out on 52 3-month-old male C57BL/6 mice with an average body weight of $23 \mathrm{~g}$, purchased from the Rappolovo breeding farm (Leningrad region). The study was hosted by Saint Petersburg State Chemical and Pharmaceutical University. The animals were fed a complete feed ration
(Laboratorkorm; Russia) and provided with drinking water (Russian GOST 2874-82), except for the period of high-calorie diet. Food and water were available ad libitum. C57BL/6 mice develop metabolic, behavioral and cognitive disorders when fed a high-fat diet, which determined the choice of this strain for the study $[10,11]$. After a 14-day acclimation period, the mice were randomized into the following experimental groups: group 1 (intact animals; $n=10$ ), group 2 (control animals with induced NAFLD that did not receive any treatment; $n=14$ ), group 3 (EMPA; NAFLD+2 mg/kg empagliflozin marketed as Jardiance $\left.{ }^{\oplus} ; n=14\right)$, and group 4 (OA; NAFLD + $1.5 \mathrm{~g} / \mathrm{kg}$ L-ornithine L-aspartate marketed as Hepa-Merz ${ }^{\oplus} ; n=14$ ). The drugs were administered by intragastric gavage once a day throughout the experiment; the control and intact groups received equivalent volumes of sodium chloride $0.9 \%$.

NAFLD (steatohepatitis) was modeled by feeding the mice a Western diet and administering carbon tetrachloride $\left(\mathrm{CCl}_{4}\right)$ intraperitoneally (Fig. 1A). The control, EMPA and OA groups were fed a high-calorie diet (HCD) for 6 months. The diet was composed of $36.65 \%$ standard chow $+21.1 \%$ beef tallow $+41 \%$ D-fructose $+1.25 \%$ cholesterol. Additionally, the drinking water was replaced with a $42 \mathrm{~g} / \mathrm{L}$ D-fructose solution. Throughout the HCD part of the experiment, the animals received intraperitoneal injections of CCl4 $(0.32 \mu \mathrm{g} / \mathrm{kg})$ once a week [12]. The intact animals received the standard feed ration and pure drinking water.

After the HCD part of the experiment was completed, animal behavior was assessed in the open field test (OF), the light/dark box test (LDB), and the elevated plus maze test (EPM) (all by Open Science; Russia). The mice were video recorded using a VideoMot2 system (TSE Systems; Germany).

The short-term and long-term spatial memory of the animals was evaluated in the Barnes maze (BM) (Open Science; Russia) [13]. After 4 days of training (4 trials per day), probe trials were conducted on days 5 and 12 . In this test, we measured the time it took the animal to reach the target box (seconds) and counted the number of mistakes.

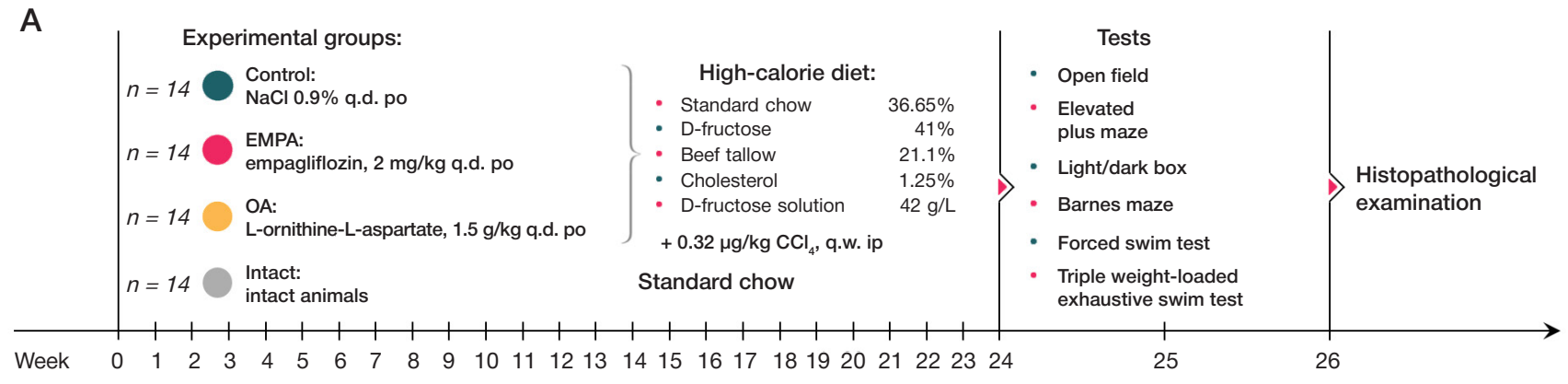

B

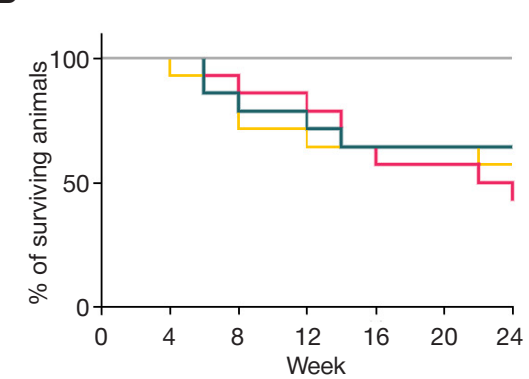

C

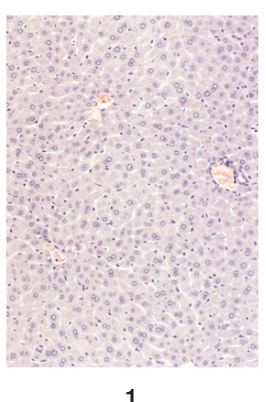

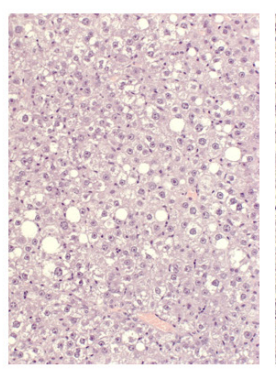

3

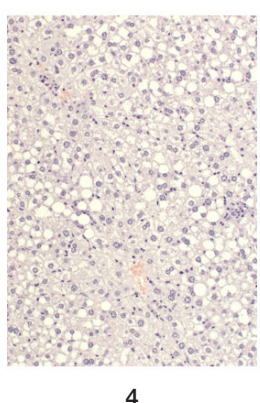

4

Fig. 1. A. Description of the NAFLD model, animal groups and the experimental design. Abbreviations: q.d. — once a day, q.w.- once a week, po — orally, ip — intraperitoneally. B. Survival dynamics. C. Histopathological slides of the liver. 1. No structural abnormalities in liver tissue in the intact group; 2. Morphological features of NAFLD in the control group, including marked macrovesicular steatosis and marked ballooning degeneration of hepatocytes, focal parenchymal infiltration by polymorphonuclear leukocytes; 3 . Morphological features of NAFLD in the EMPA group, including mild macrovesicular steatosis and mild ballooning degeneration of hepatocytes, no pathological infiltration of the liver parenchyma; 4. Moderate macrovesicular steatosis and moderate ballooning of hepatocytes, moderate parenchymal infiltration by polymorphonuclear cells in the OA group. A, B, C, D - hematoxylin-eosin staining, $\times 200$ 
Two days after the behavioral tests, the weight-loaded (7.5\% of body weight) forced swim test (FS) and the triple weightloaded exhaustive swim test (TES) $[14,15]$ were conducted to evaluate the physical performance of the animals. In the second test, swimming time was measured for each mouse at the beginning of the trial, 5 minutes later and 45 minutes later.

Morphological changes in the liver were evaluated by histology. Samples of liver tissue were fixed in 10\% buffered formalin, dehydrated, cleared in isopropanol, and embedded in paraffin using a conventional technique. Four- $\mu$ m sections prepared from paraffin blocks were mounted on slides, stained with hematoxylineosin and coverslipped. The slides were examined in incident light. Steatosis, ballooning degeneration of hepatocytes, and infiltration of the parenchyma were evaluated qualitatively $[2,16]$.

Statistical analysis was carried out in GraphPad Prism 8.0.2 (GraphPad Software; USA). Normality of distribution of quantitative variables was tested using the Shapiro-Wilk W-test. If the distribution was normal, the differences were assessed using ANOVA followed by Dunnett's post-hoc test. If the distribution was non-normal, the Kruskal-Wallis was applied followed by Dunn's multiple comparison. Below, numeric data appearing in the figures are presented as $\mathrm{M} \pm \mathrm{SE}$. The principal component analysis was done in MS Excel XLStat 2016 (Addinsoft; France).

\section{RESULTS}

\section{Animal survival and pathomorphological liver features in experimentally induced NAFLD}

Forty percent of the animals from all the experimental and control groups died during the 6 months of the study. Neither empagliflozin nor OA had any effect on animal survival (Fig. 1B).
On histology, the liver specimens of mice with induced NAFLD were characterized by steatosis, ballooning degeneration of hepatocytes, and parenchymal infiltration by polymorphonuclear leukocytes. The changes in liver morphology were the most pronounced in the control group: steatosis affected at least $30 \%$ of hepatocytes; ballooning degeneration occurred in at least $30 \%$ of liver cells. Focal infiltration of the parenchyma by polymorphonuclear leukocytes was another remarkable histologic feature in the experimental groups. Empagliflozin and OA reduced the degree of these NAFLD-associated pathological changes (Fig. 1C).

\section{Effects of experimentally induced NAFLD on measured parameters in the control group}

Behavioral tests demonstrated that steatohepatitis affected animal behavior, cognitive functions and physical performance. In the OF test, mice with experimentally induced NAFLD moved more slowly $(-38 \% ; p<0.01)$, had a longer total freezing time $(-35 \% ; p<0.01)$ and a higher number of rearing episodes $(+432 \% ; p<0.05)$ (Fig. 2A). In the control group, the number of rearing episodes and head dips in the EPM test was also higher (+279\%, $p<0.05$ and $+553 \%, p<0.05$, respectively; Fig. 2B). In the LDB and OF tests, mice with NAFLD had a lower locomotion speed $(-35 \% ; p<0.01)$ than healthy animals (Fig. 2 C).

Although the overall learning performance in the BM test was similar between the groups (the animals made fewer errors over time and needed less time to locate the target box), the latency to locate the target box was increased in the control group (+108\%) and the error rate was higher (+439\%) on day 12 , as compared to day 5 ( $p<0.05$ in both cases) (Fig. 3).

Active swimming time in the forced swim test $(-50 \%$; $p<0.05)$, as well as time spent swimming during the first trial of
A

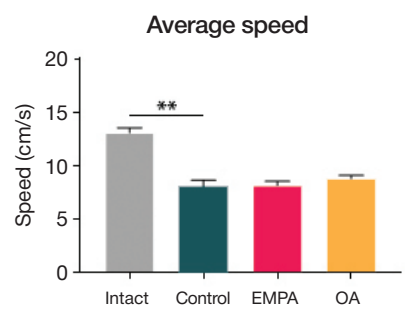

B

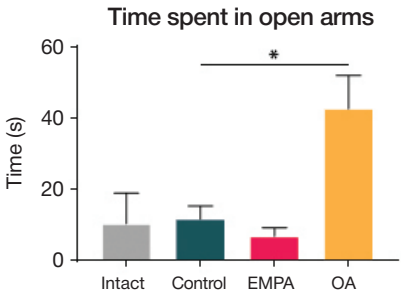

C

Time spent in light compartment Average speed in light compartment
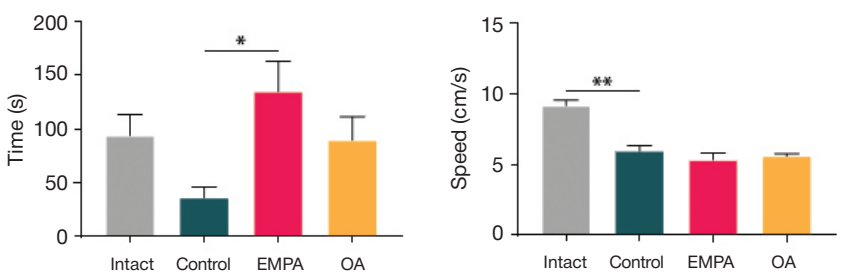

Total freezing time

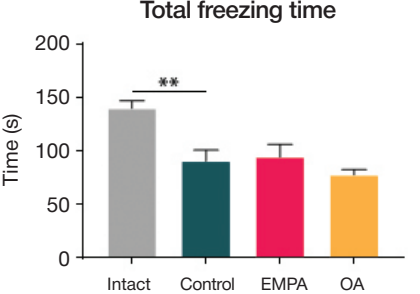

\section{Open field}
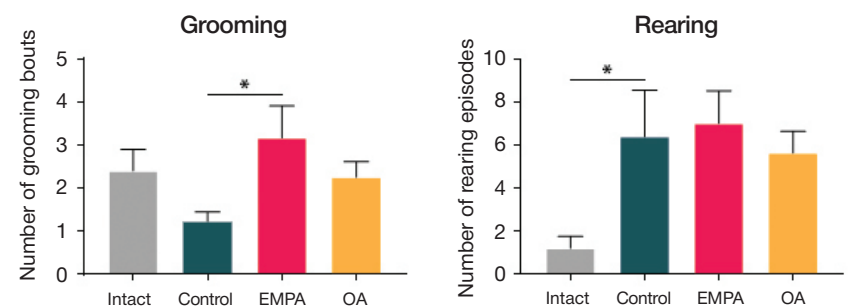

Elevated plus maze
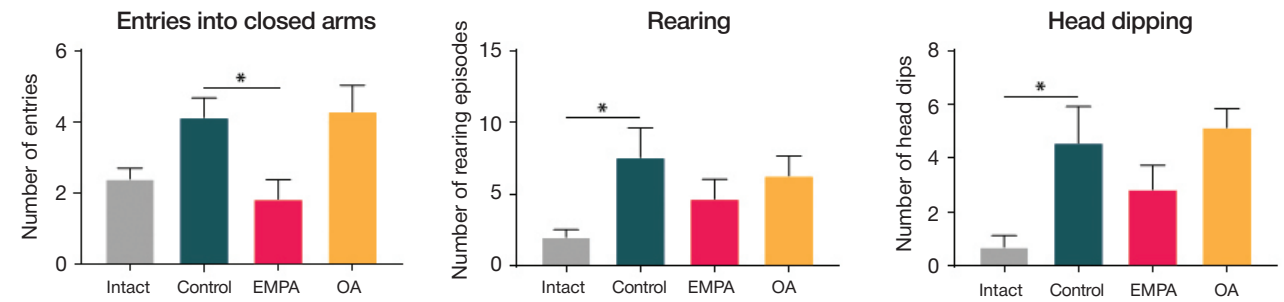

Light/dark box

Latency to first transition (L-D)

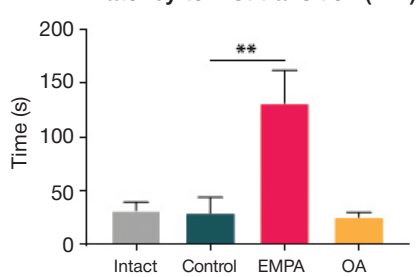

Grooming

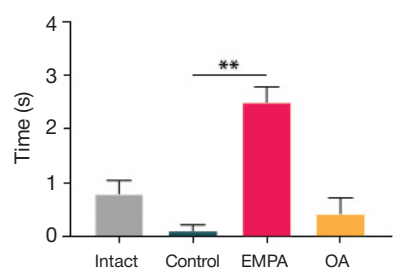

Fig. 2. Results of $(\mathbf{A})$ the Open field test, $(\mathbf{B})$ the Elevated plus maze test and $(\mathbf{C})$ the Light/dark box test. * $-p<0.05$; ${ }^{* \star}-p<0.01$ 
the triple weight-loaded exhaustive swim test $(-69 \% ; p<0.05)$, was shorter in the untreated NAFLD group than in the intact group. Besides, during the triple weight-loaded exhaustive swim test the control group required more time to recover, and their results during the second trial (5 min after the 1st trial) were not as good as those of healthy animals $(-63 \% ; p<0.05)$ (Fig. 4).

\section{Effects of empagliflozin on measured parameters}

The number of grooming bouts in the OF test was higher in the animals treated with empagliflozin $(+160 \% ; p<0.05)$ (Fig. 2A), whereas the number of visits to the closed arms in the EPM test was lower in those animals than in the control group (-56\%; $p<0.05$ ) (Fig. 2B). In the LDB test, mice treated with empagliflozin spent more time in the illuminated compartment (+275\%; $p<0.05)$, took more time to enter the dark compartment for the first time $(+355 \% ; p<0.01)$, and engaged in significantly more grooming bouts in comparison with the control group (+2173\%; $p<0.01$ ) (Fig. 2C).

Empagliflozin did not have any significant effect on the short- and long-term memory and physical performance of mice with induced NAFLD in the BM test and both forced swim tests, respectively.

\section{Effects of L-ornithine L-aspartate on measured parameters}

No significant effect of $O A$ on animal behavior and performance was noticed in the OF, LDB and BM tests. In the EPM test, time spent in the open arms of the maze was longer in the animals treated with OA than in the control group $(+267 \%$; $p<0.05)$ (Fig. 2B).

The animals treated with $\mathrm{OA}$ spent more time swimming actively than the control group (+106\%; $p<0.05)$; their results were comparable with those of the healthy animals. Similarly, in the TFS test, the mice from the OA group were able to keep their heads above the water surface longer than the untreated
NAFLD animals $(+137 \%$; $p<0.01) 45$ minutes after the first trial (Fig. 4).

\section{DISCUSSION}

This study investigated potential effects of empagliflozin and OA on behavior, memory and physical performance in C57BL/6 mice with the steatohepatitis stage of NAFLD.

In the OF and EPM tests, the mice with experimentally induced NAFLD had more episodes of rearing behavior than the controls; they also performed more head dips in the open arms of the EPM. The increased rearing frequency could be interpreted as a sign of anxiety [17, 18]. Head dipping in the open arm areas is not only an exploratory, but also a risk assessment behavior [19]. Therefore, increased head dipping is an ambiguous behavioral marker. Considering the increased rearing frequency and the propensity to visit the closed arms, head dipping in our experiment might be interpreted as a sign of anxiety [20, 21].

Unlike the intact group, mice with NAFLD engaged in grooming less often in the LDB test and tended to spend more time in the brightly illuminated compartment. Preference of dark enclosed spaces based on the hole reflex indicates increased anxiety in rodents [22]. High anxiety levels in rodents with induced NAFLD were previously reported by other authors $[23,24]$. Along with mood swings and apathy, anxiety-like behavior is a typical neurological symptom in human patients with NAFLD [3, 6].

On average, animals with experimentally induced NAFLD ambulated more slowly in the OF and LDB tests than intact animals (this parameter was not evaluated in the EPM test). The decrease in locomotion speed was not improved by empagliflozin or OA. Besides, total freezing time was shorter in all groups of animals with NAFLD. A reduction in average locomotion speed might be interpreted as a manifestation of anxiety. In the classic sense, shorter freezing time indicates an anxiolytic effect. On the other hand, it might suggest that mice

\section{Barnes maze}

Time to find the target box
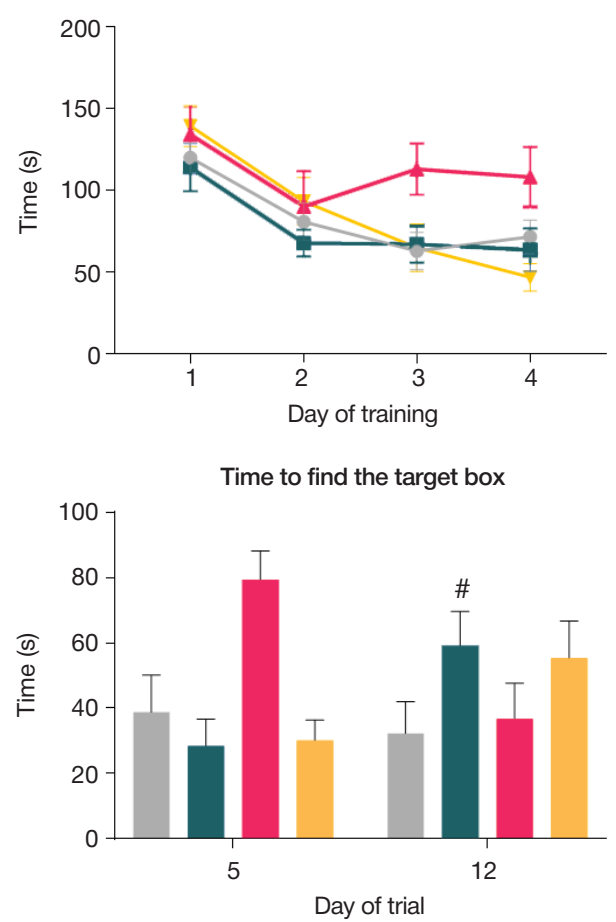

Errors
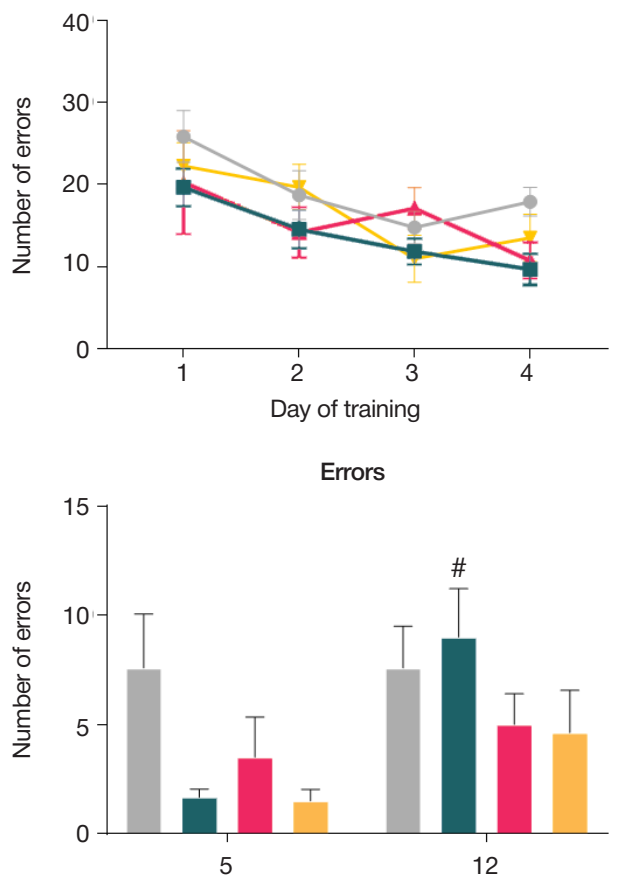

Day of trial

Fig. 3. Results of spatial memory assessment in the Barnes maze. $\square-$ Intact, $\square-$ Control, $\square-$ EMPA, $\square-\mathrm{OA}$; \# $-p<0.05$, day 12 vs day 5 
in our experiment were actively seeking shelter because of high anxiety levels. We decided to give special emphasis to changes in these parameters since it can be difficult to interpret them unequivocally. It is possible that NAFLD causes more complex behavioral changes that cannot be interpreted only in terms of high/low anxiety levels.

Mice treated with empagliflozin spent more time in the brightly illuminated compartment in the LDB test than the control group. Apparently, the animals felt less discomfort and a less pronounced need to seek shelter when placed in the light compartment. As a result, latency to the first transition into the dark compartment increased. Besides, during their visits to the light compartment, mice treated with empagliflozin performed more grooming bouts than the control animals. A similar increase in the number of grooming bouts was observed in the OF test. There are thought to be two sides to this phenomenon. On the one hand, stressed animals show a propensity to engage in shorter yet more frequent grooming bouts, which, along with increased urination and defecation, might indicate high levels of anxiety. In this case, grooming replaces other behaviors and activities inhibited by acute stress [25]. On the other hand, rodents perform more grooming bouts when they feel safe, calm and free of anxiety [26]. Considering that animals in our experiment preferred open, brightly illuminated spaces, the increased grooming frequency might reflect the anxiolytic effect of the tested drug.

Behavioral changes described above might be directly linked to the beneficial effect of empagliflozin on the morphology of glial cells [27] and to elevated BDNF (brain-derived neurotrophic factor) levels observed in mice with obesity and insulin resistance [28]. This allowed us to hypothesize that empagliflozin might have additional central mechanisms mediating its anxiolytic action.

Mice treated with OA spent more time in the open arms of the EPM, which indicates an anxiolytic effect of this drug. The unchanged closed arm entry and head dipping frequencies may indicate retention of spontaneous motor and exploratory activities in this group of animals [29].

Following a period of training for the BM test, the animals in all experimental groups were able to find the target box faster and to make less errors. The control group was the only one whose performance on day 12 was much worse than on day 5 . This might indicate a long-term memory deficit in mice with induced NAFLD. Previously, spatial memory deficits were reported in rats with NAFLD [30]. NAFLD-associated cognitive impairment was experimentally correlated to shrinkage of both gray and white brain matter and was accompanied by brain mass reduction [31]. Another study demonstrated that

A

Forced swim test

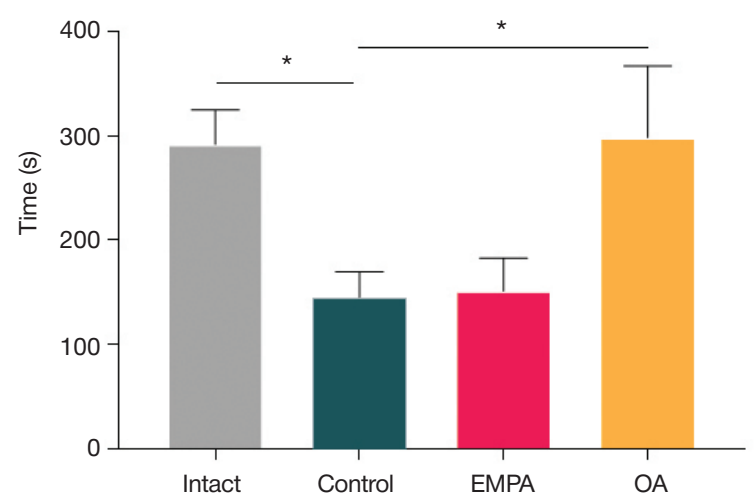

non-alcoholic steatohepatitis and liver fibrosis, especially in its late stages, caused multiple focal lesions in the white matter regardless of the presence of comorbidities [32]. In our experiment, long-term memory was compromised neither in the group of mice treated with the tested drugs nor in the intact animals.

On days 3, 4 and 5 of the experiment, mice treated with empagliflozin performed slightly worse, needing more time to find the target box in comparison with other animal groups. Those mice did not attempt to explore the maze and seek shelter but instead preferred to stay in the open space in a random hole. This is consistent with our previous proposition about the anxiolytic effect of empagliflozin, which in our case promoted resilience to stress caused by open spaces and bright light.

Earlier studies demonstrated that transfer from a normal feed ration to a high-calory diet used to model NAFLD resulted in a relatively fast (by the end of month 1) twofold drop in physical performance [33]. Starting from month 4 of the highcalorie diet, the mice were gradually restoring their initial level of performance. However, the metabolic burden of excess calories was more extreme in our experiment. This might explain why the mechanisms involved in energy production had not adapted to the new conditions by month 6 and physical performance of the animals in the forced swim test was significantly worse (45\% relative to the results of the intact group that had fully restored the level of physical performance by month 6 of a less strict diet).

Importantly, even milder models of NAFLD can result in a significant decline in glycogen levels in skeletal muscles (by 33\%) and liver (by 44\%) [33]. A combination of a high-calorie diet and injections of $\mathrm{CCl}_{4}$, which exerts hepatotoxic and prooxidant effects, leads to the development of pronounced disturbances in lipid metabolism with typical morphological changes to liver tissue visible on histology, can further aggravate cognitive and behavioral deficits and compromise physical performance [12]. Carbohydrate deficiency in skeletal muscles could be the underlying metabolic cause of poor physical performance in laboratory animals. In our study, repeated administration of empagliflozin did not have a positive effect on the physical performance of mice in the forced swim test. This was predictable because empagliflozin does not improve glucose transport to muscle cells and does not stimulate glycogen synthesis.

Breakdown of muscle proteins and participation of amino acids in the production of substrates for the Krebs cycle provide energy for muscle work. These processes are accompanied by vigorous production of ammonia, which is then utilized in

\section{B Triple weight-loaded exhaustive swim test}

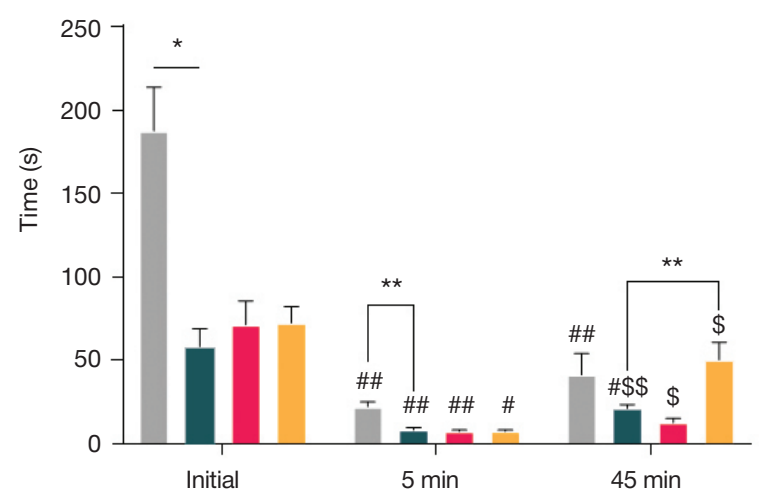

Fig. 4. Results of the Forced swim test (A) and the Triple weight-loaded exhaustive swim test (B). $\square-$ Intact, $\square-$ Control, $\square-$ EMPA, $\square-$ OA; ${ }^{\star}-p<0.05 ;{ }^{\star \star}-$ $p<0.01$; \# $-p<0.05$; \#\# $-p<0.01$, comparison with the initial result; $\$-p<0.05, \$ \$-p<0.01$, comparison with the second trial (5 min after the first trial) 
the ornithine cycle of urea synthesis. In humans, OA activates the urea cycle, enhances lipid metabolism, slightly elevates the level of ketone bodies and free fatty acids, lowers blood ammonia, and alleviates the subjective feeling of fatigue [34]. In our study, repeated administration of OA significantly mitigated the noxious effect of NAFLD on the physical performance of mice in the forced swim tests, demonstrating the special role of amino acid utilization in providing energy for muscle work in a situation of a high-calorie diet, when the organism's metabolism has to adjust to the new conditions

To elucidate the mechanism of OA effects on the physical performance of mice with experimentally induced NAFLD, the TFS test was conducted. The initial-to-exhausting swimming time ratio (the total duration of the first and second trials) in the intact group revealed that the animals refused to continue swimming because of physical exhaustion; the contribution of the central nervous system component was minor [35]. In mice with experimentally induced NAFLD, the duration of active swimming was three times shorter in the first trial, suggesting diminished endurance with a central nervous system and a peripheral organ components. Repeated administration of empagliflozin and OA decreased the contribution of the central (but not the peripheral) component, which was indicated by a $40 \%$ decline in the physical performance compared to the intact group.

The main TFS parameter (exhaustion index, El) characterizes the efficacy of recovery mechanisms in the first phase of recovery after exhaustive exercise. This parameter is calculated as a ratio of weight-loaded swimming duration after $45 \mathrm{~min}$ of the recovery period to the duration of exhaustive swimming. Immediate recovery occurs in the first $0.5-1.5 \mathrm{~h}$ of the resting phase and is essentially based on the excretion of anaerobic metabolism products accumulated during exercise and the repayment of oxygen debt. It should be noted that in the immediate phase of post-exercise recovery, oxidative phosphorylation does not play a key role in the resynthesis of adenosine triphosphate (ATP). More important here (especially in a situation of exhaustive exercise, fatigue or overtraining) is the alactic pathway, which uses adenosine diphosphate (ADP), the product of ATP degradation), for ATP resynthesis. This mechanism is launched when ADP concentrations are high in muscle cells, which occurs only when other pathways for ADP resynthesis have been depleted. To ensure the high rate of the myokinase reaction, adenosine monophosphate needs to be degraded further and its metabolite, inosine monophosphate, needs to be excreted from the muscles. These events are closely associated with ammonia synthesis by actively working skeletal muscles [36].

The El analysis revealed that empagliflozin did not affect the processes unfolding in the first recovery phase (TI was 0.20 in the intact group, 0.19 in the EMPA group and 0.38 in the control group due to a steep reduction in endurance and shorter duration of the exhaustive exercise). At the same time, El was 0.61 in mice treated with $O A$, suggesting a significant effect of the drug on post-exercise recovery. Perhaps, this could explain the restoration of physical performance in mice treated with $\mathrm{OA}$. The effect of L-ornithine and its salts on postexercise recovery, as well as the achievement of the desired training effect, in healthy humans and laboratory animals is a well-known phenomenon in sports medicine [37-39]. However, its impact on physical performance and the efficiency of the first phase of recovery after exhaustive exercise in a NAFLD model has never been demonstrated before.

The principal component analysis of all experimental data detected significant differences between intact and control animals. The effects of the studied drugs were not limited to mitigation of NAFLD symptoms: some of them were unrelated to the studied pathology (Fig. 5). Repeated administration of empagliflozin and $\mathrm{OA}$ can improve the histomorphological appearance of the liver and correct some symptoms often present in NAFLD, including anxiety, depression, cognitive deficit and asthenia. These effects might be clinically relevant due to the high prevalence of NAFLD in the economically active population.

\section{PCA3}

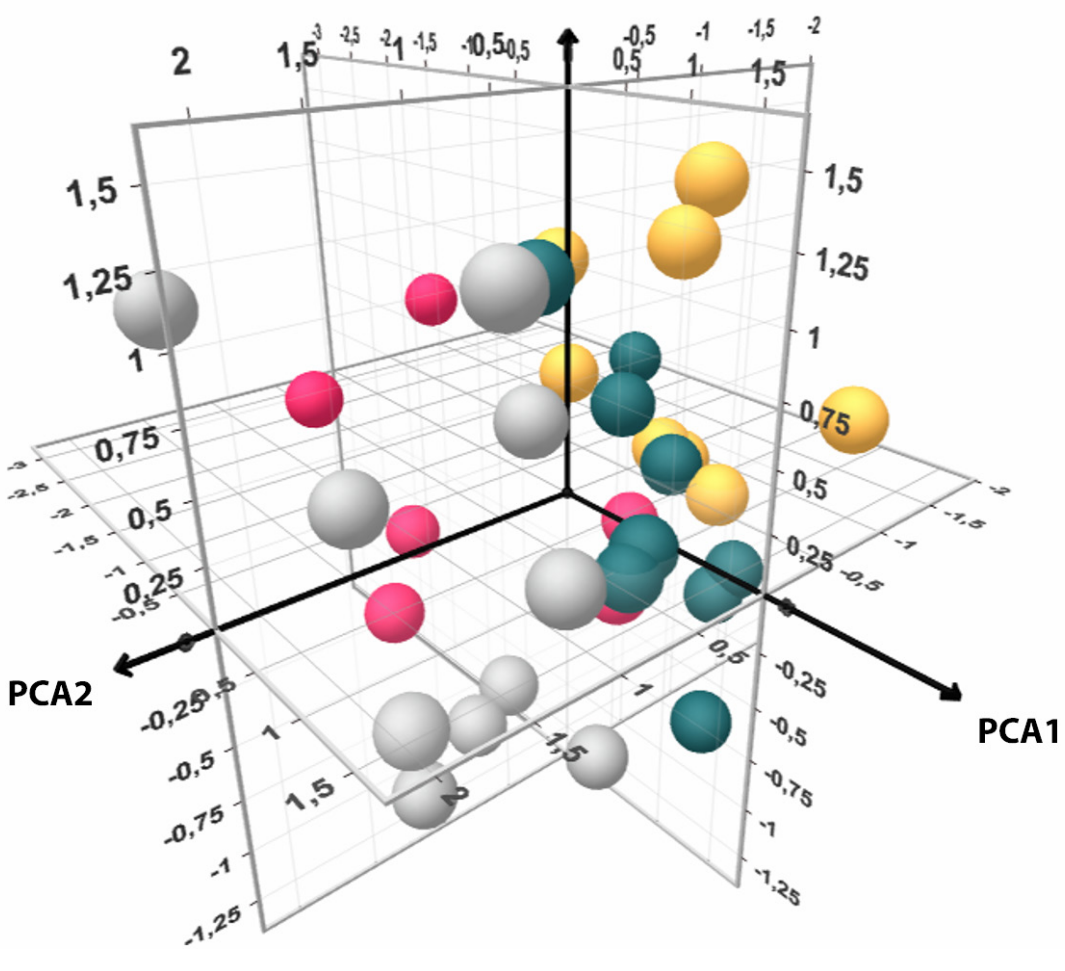

Fig. 5. Graphic representation of principal component analysis results. $\square-$ Intact, $\square-$ Control, $\square-$ EMPA, $\square-\mathrm{OA}$ 


\section{CONCLUSIONS}

1. Experimentally induced NAFLD causes pronounced behavioral changes in C57BL/6 mice. These changes include increased anxiety, long-term memory deficit, and poor physical performance. 2. Repeated administration of empagliflozin and $\mathrm{OA}$ can mitigate anxiety-like behavior and improve the affected cognitive functions to some extent. 3. OA can correct asthenia manifesting as poor physical performance in mice with NAFLD.

\section{References}

1. Younossi ZM. Non-alcoholic fatty liver disease - A global public health perspective. J Hepatol. 2018; 70 (3): 531-44. PubMed PMID: 30414863.

2. Ivashkin VT, Mayevskaya MV, Pavlov ChS, Tikhonov IN, Shirokova YeN Buyeverov AO, et al. Diagnostics and treatment of non-alcoholic fatty liver disease: clinical guidelines of the Russian Scientific Liver Society and the Russian gastroenterological association. Russian Journal of Gastroenterology, Hepatology, Coloproctology. 2016; 26 (2): 24-42.

3. Moretti R, Caruso P, Gazzin S. Non-alcoholic fatty liver disease and neurological defects. Ann Hepatol. 2019; 18 (4): 563-570. PubMed PMID: 31080056.

4. Newton JL. Systemic Symptoms in Non-Alcoholic Fatty Liver Disease. Dig Dis. 2010; 28 (1): 214-9. PubMed PMID: 20460914

5. Weinstein G, Davis-Plourde K, Himali JJ, Zelber-Sagi S, Beiser AS, Seshadri S. Non-alcoholic fatty liver disease, liver fibrosis score and cognitive function in middle-aged adults: The Framingham Study. Liver Int. 2019; 39 (9): 1713-21. PubMed PMID: 31155826.

6. Youssef NA, Abdelmalek MF, Binks M, Guy CD, Omenetti A, Smith AD, et al. Associations of depression, anxiety and antidepressants with histological severity of nonalcoholic fatty liver disease. Liver Int. 2013; 33 (7): 1062-70. PubMed PMID: 23560860.

7. Chalasani N, Younossi Z, Lavine JE, Charlton M, Cusi K, Rinella M, et al. The diagnosis and management of nonalcoholic fatty liver disease: practice guidance from the American Association for the Study of Liver Diseases. Hepatology. 2018; 67 (1): 328-57.

8. Dudarenko SV, Kovalenko AL, Prokopenko SM, Belogurova EV. The use of remaxol in the treatment of metabolic syndrome in patients with nonalcoholic steatohepatitis and diabetes mellitus 2 type. Experimental \& Clinical Gastroenterology. 2016: 130 (6): 89-94.

9. Mayevskaya MV, Ivashkin VT, Lunkov VD, Kryzhanovskiy SP, Pirogova IYu, Pavlov CS et al. Antioxidants in the treatment of chronic diffuse liver diseases (the results of the "MAXAR" observational program). Russian Journal of Gastroenterology, Hepatology, Coloproctology. 2018; 28 (5): 77-97.

10. Montgomery MK, Hallahan NL, Brown SH, Liu M, Mitchell TW, Cooney GJ, et al. Mouse strain-dependent variation in obesity and glucose homeostasis in response to high-fat feeding. Diabetologia. 2013; 56 (5): 1129-39. PubMed PMID: 23423668.

11. Almeida-Suhett CP, Graham A, Chen Y, Deuster P. Behavioral changes in male mice fed a high-fat diet are associated with IL-1 $\beta$ expression in specific brain regions. Physiol Behav. 2017; 169: 130-40. PubMed PMID: 27876639.

12. Tsuchida T, Lee AY, Fujiwara N, Ybanez M, Allen B, Martins S, et al. A simple diet- and chemical-induced murine nash model with rapid progression of steatohepatitis, fibrosis and liver cancer. $J$ Hepatol. 2018; 69 (2): 385-95. PubMed PMID: 29572095.

13. Pitts MW. Barnes maze procedure for spatial learning and memory in mice. Bio Protoc [Internet]. 2018 Mar [cited 2020 May 01]; 8 (5): e2744. Available from: https://bio-protocol.org/e2744.

14. Karkishchenko NN, Karkishchenko VN, Shustov EB, Berzin IA, Kapanadze GD, Fokin YuV et al. Biomeditsinskoe (doklinicheskoe) izuchenie lekarstvennykh sredstv, vliyayushchikh na fizicheskuyu rabotosposobnost'. Metodicheskie rekomendatsii. M.: Nauchnyy tsentr biomeditsinskikh tekhnologiy Federal'nogo medikobiologicheskogo agentstva, 2017; 134 p. Russian.

15. Radko SV, Gusev KA, Krasnova MV, Okovityy SV, inventors: Saint Petersburg State Chemical Pharmaceutical University (SPCPU), assignee. Ustroystvo dlya krepleniya gruzov k melkim laboratornym zhivotnym. Russian Federation patent № 172475.

07.11.2017. Russian

16. Marchesini G, Day CP, Dufour JF, Canbay A, Nobili V, Ratziu V et al. EASL-EASD-EASO Clinical Practice Guidelines for the management of non-alcoholic fatty liver disease. J Hepatol. 2016; 64 (6): 1388-402. PubMed PMID: 27062661.

17. Diaz-Moran S, Estanislau C, Canete T, Blazquez G, Raez A, Tobena A et al. Relationships of open-field behaviour with anxiety in the elevated zero-maze test: focus on freezing and grooming. World J Neurosci. 2014; 4: 1-11

18. Eudave DM, BeLow NM, Flandreau El. Effects of high fat or high sucrose diet on behavioral-response to social defeat stress in mice. Neurobiol Stress. 2018; 9: 1-8. PubMed PMID: 30003122.

19. Sestakova N, Puzserova A, Kluknavsky M, Bernatova I. Determination of motor activity and anxiety-related behaviour in rodents: methodological aspects and role of nitric oxide. Interdiscip Toxicol. 2013; 6 (3): 126-35. PubMed PMID: 24678249.

20. Aduema W, Osim EE, Nwankwo AA. Using the elevated plus maze task in assessing anxiety and fear in swiss white mice. $J$ Complement Med Alt Healthcare [Internet]. 2018 Apr [cited 2020 May 01]; 6 (1): 555678. Available from: https://juniperpublishers. com/jcmah/JCMAH.MS.ID.555678.php.

21. Bakhtiyarova ShK, Kapysheva UN, Ablaykhanova NT, Baimbetova AK, Zhaksymov BI, Korganbaeva AA, et al. Povedenie zhivotnykh $v$ razlichnykh testakh. Mezhdunarodnyy zhurnal prikladnykh i fundamental'nykh issledovaniy. 2017; (8): 92-96. Russian.

22. Costall B, Jones BJ, Kelly ME, Naylor RJ, Tomkins DM. Exploration of mice in a black and white test box: validation as a model of anxiety. Pharmacol Biochem Behav. 1989; 32 (3): 77785. PubMed PMID: 2740429.

23. Strekalova T, Evans M, Costa-Nunes J, Bachurin S, Yeritsyan N, Couch $\mathrm{Y}$, et al. TIr4 upregulation in the brain accompanies depression- and anxiety-like behaviors induced by a highcholesterol diet. Brain Behav Immun. 2015; 48: 42-7. PubMed PMID: 25712260.

24. Zemdegs J, Quesseveur G, Jarriault D, Penicaud L, Fioramonti X, Guiard BP. High-fat diet-induced metabolic disorders impairs $5-\mathrm{HT}$ function and anxiety-like behavior in mice. $\mathrm{Br} \mathrm{J}$ Pharmacol. 2016; 173 (13): 2095-110. PubMed PMID: 26472268.

25. Kalueff AV, Keisala T, Minasyan A, Kuuslahti M, Tuohimaa P. Temporal stability of novelty exploration in mice exposed to different open field tests. Behav Processes. 2006; 72 (1): 104-12. PubMed PMID: 16442749.

26. Kalueff AV, Tuohimaa P. Grooming analysis algorithm for neurobehavioural stress research. Brain Res Brain Res Protoc. 2004; 13 (3): 151-8. PubMed PMID: 15296852.

27. Hayden MR, Grant DG, Aroor AR, DeMarco VG. Empagliflozin ameliorates type 2 diabetes-induced ultrastructural remodeling of the neurovascular unit and neuroglia in the female $\mathrm{db} / \mathrm{db}$ mouse. Brain Sci [Internet]. 2019 Mar [cited 2020 May 01]; 9 (3): 57. Available from: https://www.mdpi.com/2076-3425/9/3/57. PubMed PMID: 30866531

28. Lin B, Koibuchi N, Hasegawa Y, Sueta D, Toyama K, Uekawa K, et al. Glycemic control with empagliflozin, a novel selective SGLT2 inhibitor, ameliorates cardiovascular injury and cognitive dysfunction in obese and type 2 diabetic mice. Cardiovasc Diabetol. 2014; 13: 148. PubMed PMID: 25344694.

29. Walf AA, Frye CA. The use of the elevated plus maze as an assay of anxiety-related behavior in rodents. Nat Protoc. 2007; 2 (2): 322-8. PubMed PMID: 17406592.

30. Ross AP, Bruggeman EC, Kasumu AW, Mielke JG, Parent MB. 
Non-alcoholic fatty liver disease impairs hippocampal-dependent memory in male rats. Physiol Behav. 2012; 106 (2): 133-41. PubMed PMID: 22280920.

31. Filipovic B, Markovic O, Duric V, Filipovic B. Cognitive changes and brain volume reduction in patients with nonalcoholic fatty liver disease. Can J Gastroenterol Hepatol [Internet]. 2018 Feb [cited 2020 May 01]; 2018: 9638797. Available from: https:// www.hindawi.com/journals/cjgh/2018/9638797/. PubMed PMID: 29682494

32. Petta S, Tuttolomondo A, Gagliardo C, Zafonte R, Brancatelli, Cabibi $\mathrm{D}$, et al. The presence of white matter lesions is associated with the fibrosis severity of nonalcoholic fatty liver disease. Medicine (Baltimore) [Internet]. 2016 Apr [cited 2020 May 01]; 95 (16): e3446. Available from: https://journals.Iww.com/md-journal/ fulltext/2016/04190/ The_Presence_of_White_Matter_Lesions_ Is_Associated.35.aspx. PubMed PMID: 27100443.

33. Okovitiy SV, Shustov EB, Belyh MA, Kirillova NV, Spasenkova OM, Ivanov AG, et al. Modeling of non-alcoholic liver steatosis: features of metabolic changes in the body of laboratory animals. Biomedicine. 2018; (4): 29-43.

34. Sugino T, Shiri T, Kajimoto $\mathrm{Y}$, Kajimoto O. L-ornithine supplementation attenuates physical fatigue in healthy volunteers by modulating lipid and amino acid metabolism. Nutr Res. 2008; 28 (11): 738-43. PubMed PMID: 19083482.

35. Karkischenko VN, Karkischenko NN, Shustov EB, Berzin IA, Fokin YuV, Alimkina OV. Features interpretation of laboratory animal health indicators in swimming tests with load. Biomedicine. 2016; (4): 34-46.

36. Banister EW, Cameron BJC. Exercise-induced hyperammonemia: peripheral and central effects. Int J Sports Med. 1990; 11 (Suppl 2): S129-42. PubMed PMID: 2193891.

37. Demura S, Yamada T, Yamaji S, Komatsu M, Morishita K. The effect of L-ornithine hydrochloride ingestion on human growth hormone secretion after strength training. Advances in Bioscience and Biotechnology. 2010; 1 (1): 7-11.

38. Okovity SV, Radko SV, Krasnova MV. Experimental assessment of influence of L-ornithine-L-aspartate on physical efference. Lechebnaya fizkul'tura i sportivnaya meditsina. 2017; 4 (142): 25-33.

39. Rodichkin PV, Ponomarev GN, Pupkov PV, Orlov AS Hepatoprotectors to build strength in athletes. Theory and Practice of Physical Culture. 2019; (10): 89-91.

\section{Литература}

1. Younossi ZM. Non-alcoholic fatty liver disease - A global public health perspective. J Hepatol. 2018; 70 (3): 531-44. PubMed PMID: 30414863

2. Ивашкин В. Т., Маевская М. В., Павлов Ч. С., Тихонов И. Н., Широкова Е. Н., Буеверов А. О. и др. Клинические рекомендации по диагностике и лечению неалкогольной жировой болезни печени Российского общества по изучению печени и Российской гастроэнтерологической ассоциации. Российский журнал гастроэнтерологии, гепатологии, колопроктологии. 2016; 26 (2): 24-42.

3. Moretti R, Caruso P, Gazzin S. Non-alcoholic fatty liver disease and neurological defects. Ann Hepatol. 2019; 18 (4): 563-570. PubMed PMID: 31080056

4. Newton JL. Systemic Symptoms in Non-Alcoholic Fatty Liver Disease. Dig Dis. 2010; 28 (1): 214-9. PubMed PMID: 20460914.

5. Weinstein G, Davis-Plourde K, Himali JJ, Zelber-Sagi S, Beiser AS, Seshadri S. Non-alcoholic fatty liver disease, liver fibrosis score and cognitive function in middle-aged adults: The Framingham Study. Liver Int. 2019; 39 (9): 1713-21. PubMed PMID: 31155826.

6. Youssef NA, Abdelmalek MF, Binks M, Guy CD, Omenetti A, Smith AD, et al. Associations of depression, anxiety and antidepressants with histological severity of nonalcoholic fatty liver disease. Liver Int. 2013; 33 (7): 1062-70. PubMed PMID: 23560860.

7. Chalasani N, Younossi Z, Lavine JE, Charlton M, Cusi K, Rinella M, et al. The diagnosis and management of nonalcoholic fatty liver disease: practice guidance from the American Association for the Study of Liver Diseases. Hepatology. 2018; 67 (1): 328-57.

8. Дударенко С. В., Коваленко А. Л., Прокопенко С. М., Белогурова Е. В. Применение ремаксола в терапии метаболического синдрома у пациентов с неалкогольным стеатогепатитом и сахарным диабетом 2 типа. Экспериментальная и клиническая гастроэнтерология. 2016: 130 (6): 89-94.

9. Маевская М. В., Ивашкин В. Т., Луньков В. Д., Крыжановский С. П., Пирогова И. Ю., Павлов Ч. С. и др. Антиоксиданты в лечении хронических диффузных заболеваний печени (результать наблюдательной программы «MAXAR»). Российский журнал гастроэнтерологии, гепатологии, колопроктологии. 2018; 28 (5): 77-97.

10. Montgomery MK, Hallahan NL, Brown SH, Liu M, Mitchell TW, Cooney GJ, et al. Mouse strain-dependent variation in obesity and glucose homeostasis in response to high-fat feeding. Diabetologia. 2013; 56 (5): 1129-39. PubMed PMID: 23423668.

11. Almeida-Suhett CP, Graham A, Chen $Y$, Deuster P. Behavioral changes in male mice fed a high-fat diet are associated with IL-1 $\beta$ expression in specific brain regions. Physiol Behav. 2017; 169: 130-40. PubMed PMID: 27876639.

12. Tsuchida T, Lee AY, Fujiwara N, Ybanez M, Allen B, Martins S, et al. A simple diet- and chemical-induced murine nash model with rapid progression of steatohepatitis, fibrosis and liver cancer. $J$ Hepatol. 2018; 69 (2): 385-95. PubMed PMID: 29572095.

13. Pitts MW. Barnes maze procedure for spatial learning and memory in mice. Bio Protoc [Internet]. 2018 Mar [cited 2020 May 01]; 8 (5): e2744. Available from: https://bio-protocol.org/e2744.

14. Каркищенко Н. Н., Каркищенко В. Н., Шустов Е. Б, Берзин И. А., Капанадзе Г. Д., Фокин Ю. В. и др. Биомедицинское (доклиническое) изучение лекарственных средств, влияющих на физическую работоспособность. Методические рекомендации. М.: Научный центр биомедицинских технологий Федерального медико-биологического агентства, 2017; 134 с.

15. Радько С. В., Гусев К. А., Краснова М. В., Оковитый С. В., авторы; Федеральное государственное бюджетное образовательное учреждение высшего образования «СанктПетербургская государственная химико-фармацевтическая академия» Министерства здравоохранения Российской Федерации (ФГБОУ ВО СПХФА Минздрава России), патентообладатель. Устройство для крепления грузов к мелким лабораторным животным. Патент РФ № 172475. 07.11 .2017

16. Marchesini G, Day CP, Dufour JF, Canbay A, Nobili V, Ratziu V et al. EASL-EASD-EASO Clinical Practice Guidelines for the management of non-alcoholic fatty liver disease. J Hepatol. 2016; 64 (6): 1388-402. PubMed PMID: 27062661.

17. Diaz-Moran S, Estanislau C, Canete T, Blazquez G, Raez A Tobena $A$ et al. Relationships of open-field behaviour with anxiety in the elevated zero-maze test: focus on freezing and grooming. World J Neurosci. 2014; 4: 1-11.

18. Eudave DM, BeLow NM, Flandreau El. Effects of high fat or high sucrose diet on behavioral-response to social defeat stress in mice. Neurobiol Stress. 2018; 9: 1-8. PubMed PMID: 30003122

19. Sestakova N, Puzserova A, Kluknavsky M, Bernatova I. Determination of motor activity and anxiety-related behaviour in rodents: methodological aspects and role of nitric oxide. Interdiscip Toxicol. 2013; 6 (3): 126-35. PubMed PMID: 24678249.

20. Aduema W, Osim EE, Nwankwo AA. Using the elevated plus maze task in assessing anxiety and fear in swiss white mice. $J$ Complement Med Alt Healthcare [Internet]. 2018 Apr [cited 2020 May 01]; 6 (1): 555678. Available from: https://juniperpublishers. com/jcmah/JCMAH.MS.ID.555678.php.

21. Бахтиярова Ш. К., Капышева У. Н., Аблайханова Н. Т., Баимбетова А. К., Жаксымов Б. И., Корганбаева А. А. и др. Поведение животных в различных тестах. Международный журнал прикладных и фундаментальных исследований. 2017; (8): 92-96. 
22. Costall B, Jones BJ, Kelly ME, Naylor RJ, Tomkins DM. Exploration of mice in a black and white test box: validation as a model of anxiety. Pharmacol Biochem Behav. 1989; 32 (3): $777-$ 85. PubMed PMID: 2740429.

23. Strekalova T, Evans M, Costa-Nunes J, Bachurin S, Yeritsyan N, Couch $Y$, et al. TIr4 upregulation in the brain accompanies depression- and anxiety-like behaviors induced by a highcholesterol diet. Brain Behav Immun. 2015; 48: 42-7. PubMed PMID: 25712260.

24. Zemdegs J, Quesseveur G, Jarriault D, Penicaud L, Fioramonti X Guiard BP. High-fat diet-induced metabolic disorders impairs 5-HT function and anxiety-like behavior in mice. Br J Pharmacol. 2016; 173 (13): 2095-110. PubMed PMID: 26472268.

25. Kalueff AV, Keisala T, Minasyan A, Kuuslahti M, Tuohimaa P. Temporal stability of novelty exploration in mice exposed to different open field tests. Behav Processes. 2006; 72 (1): 104-12. PubMed PMID: 16442749.

26. Kalueff AV, Tuohimaa P. Grooming analysis algorithm for neurobehavioural stress research. Brain Res Brain Res Protoc. 2004; 13 (3): 151-8. PubMed PMID: 15296852.

27. Hayden MR, Grant DG, Aroor AR, DeMarco VG. Empagliflozin ameliorates type 2 diabetes-induced ultrastructural remodeling of the neurovascular unit and neuroglia in the female $\mathrm{db} / \mathrm{db}$ mouse. Brain Sci [Internet]. 2019 Mar [cited 2020 May 01]; 9 (3): 57. Available from: https://www.mdpi.com/2076-3425/9/3/57. PubMed PMID: 30866531.

28. Lin B, Koibuchi N, Hasegawa Y, Sueta D, Toyama K, Uekawa K, et al. Glycemic control with empagliflozin, a novel selective SGLT2 inhibitor, ameliorates cardiovascular injury and cognitive dysfunction in obese and type 2 diabetic mice. Cardiovasc Diabetol. 2014; 13: 148. PubMed PMID: 25344694.

29. Walf AA, Frye CA. The use of the elevated plus maze as an assay of anxiety-related behavior in rodents. Nat Protoc. 2007; 2 (2): 322-8. PubMed PMID: 17406592

30. Ross AP, Bruggeman EC, Kasumu AW, Mielke JG, Parent MB. Non-alcoholic fatty liver disease impairs hippocampal-dependent memory in male rats. Physiol Behav. 2012; 106 (2): 133-41. PubMed PMID: 22280920.

31. Filipovic B, Markovic O, Duric V, Filipovic B. Cognitive changes and brain volume reduction in patients with nonalcoholic fatty liver disease. Can J Gastroenterol Hepatol [Internet]. 2018 Feb [cited 2020 May 01]; 2018: 9638797. Available from: https:// www.hindawi.com/journals/cjgh/2018/9638797/. PubMed PMID: 29682494.

32. Petta S, Tuttolomondo A, Gagliardo C, Zafonte R, Brancatelli, Cabibi D, et al. The presence of white matter lesions is associated with the fibrosis severity of nonalcoholic fatty liver disease. Medicine (Baltimore) [Internet]. 2016 Apr [cited 2020 May 01]; 95 (16): e3446. Available from: https://journals.Iww.com/md-journal/ fulltext/2016/04190/ The_Presence_of_White_Matter_Lesions Is_Associated.35.aspx. PubMed PMID: 27100443.

33. Оковитый С. В., Шустов Е. Б., Белых М. А., Кириллова Н. В., Спасенкова О. М., Иванов А. Г. и др. Моделирование неалкогольного стеатоза печени: особенности метаболических изменений в организме лабораторных животных. Биомедицина. 2018; (4): 29-43.

34. Sugino $T$, Shiri $T$, Kajimoto $Y$, Kajimoto O. L-ornithine supplementation attenuates physical fatigue in healthy volunteers by modulating lipid and amino acid metabolism. Nutr Res. 2008; 28 (11): 738-43. PubMed PMID: 19083482.

35. Каркищенко В. Н., Каркищенко Н. Н., Шустов Е. Б., Берзин И. А., Фокин Ю. В., Алимкина О. В. Особенности интерпретации показателей работоспособности лабораторных животных по плавательным тестам с нагрузкой. Биомедицина. 2016; (4): 34-46.

36. Banister EW, Cameron BJC. Exercise-induced hyperammonemia: peripheral and central effects. Int J Sports Med. 1990; 11 (Suppl 2): S129-42. PubMed PMID: 2193891.

37. Demura S, Yamada T, Yamaji S, Komatsu M, Morishita K. The effect of L-ornithine hydrochloride ingestion on human growth hormone secretion after strength training. Advances in Bioscience and Biotechnology. 2010; 1 (1): 7-11.

38. Оковитый С. В., Радько С. В., Краснова М. В. Экспериментальная оценка влияния L-орнитина L-аспартата на физическую работоспособность. Лечебная физкультура и спортивная медицина. 2017; 4 (142): 25-33.

39. Родичкин П. В., Пономарев Г. Н., Пупков П. В., Орлов А. С. Оптимизация силовой подготовленности спортсменов с применением гепатопротекторов. Теория и практика физической культуры. 2019; (10): 89-91. 